\title{
Interlocução entre neurociência e aprendizagem significativa: uma proposta teórica para o ensino de genética
}

\section{RESUMO}

Fabio Seidel dos Santos fabio seidel@hotmail.com 0000-0003-0298-9548

niversidade Tecnológica Federal do Paraná, Ponta Grossa, Paraná, Brasil.

Antonio Carlos de Francisco acfrancisco@utfpr.edu.br

000-0003-0298-9548

Universidade Tecnológica Federal do Paraná, Ponta Grossa, Paraná, Brasil.

\section{Ângela Inês Klein}

angelaklein@utfpr.edu.br

0000-0003-0298-9548

Universidade Tecnológica Federal do

Paraná, Ponta Grossa, Paraná, Brasil.

Daniela Frigo Ferraz

dfrigoferraz@gmail.com

000-0003-0298-9548

Universidade Tecnológica Federal do

Paraná, Ponta Grossa, Paraná, Brasil.
Este artigo de revisão bibliográfica se propôs a verificar a possibilidade de associar os conhecimentos neurocientíficos com a Teoria da Aprendizagem Significativa de Ausubel como proposta teórica para facilitar o ensino e aprendizagem de Genética. Os resultados desta revisão mostraram que os conceitos centrais da Teoria da Aprendizagem Significativa (estrutura cognitiva, conhecimentos prévios, aprendizagem mecânica e significativa, mapas conceituais) apresentam um forte correlato neurofisiológico, por isso a interlocução entre Neurociência e Aprendizagem Significativa é possível. Diante disso, conclui-se que a Neurociência associada à Teoria da Aprendizagem Significativa resulta em uma abordagem neurocognitiva, que possibilita uma melhor compreensão dos mecanismos neurais e cognitivos envolvidos no processo de ensino e aprendizagem e, a partir disso, pode oferecer subsídios teóricos e práticos importantes para o trabalho docente, facilitando a aprendizagem significativa de Genética.

PALAVRAS-CHAVE: Neurociência. Aprendizagem significativa. Ensino de genética. 


\section{INTRODUÇÃO}

A literatura científica mostra que, no ensino de Ciências e Biologia, o conteúdo de Genética é marcado pela dificuldade de entendimento dos alunos, pois se trata de um conteúdo complexo e específico, cujas ideias exigem um elevado grau de abstração para serem compreendidas (CARDOSO et al. 2010; MARTINEZ et al. 2008). Estudos revelam que nem mesmo os conceitos básicos desta área, como a relação entre gene e cromossomo e a finalidade das divisões celulares por mitose e meiose, são compreendidas pelos alunos ao final do Ensino Médio (SCHEID e FERRARI, 2006).

Entender o conteúdo de Genética é fundamental para a compreensão de temas ainda mais complexos, tanto desta área quanto de Biologia Molecular, assim como para um posicionamento crítico diante das tecnologias que delas emergem e que, frequentemente, suscitam questionamentos éticos, morais, políticos, religiosos e econômicos, muitas vezes negligenciados pelos cientistas e desconhecidos pela sociedade em geral.

Dada à complexidade do conteúdo de Genética, os professores vêm empregando estratégias de ensino bastante variadas, com o objetivo de torná-lo mais interessante e simples de ser compreendido. Segundo Justina e Ferla (2006, p.36-37), para a alfabetização científica e tecnológica em Genética é importante que

[...] sejam ultrapassados os fatores limitantes na atividade pedagógica que são: a abordagem fragmentada e descontextualizada dos tópicos; o livro didático como único recurso didático-metodológico e o estudo da genética mendeliana em detrimento da genética moderna. Tal superação pode estar associada a uma dinâmica de aula capaz de estimular o interesse dos alunos, de instigá-los a resolver os problemas que devem emergir das próprias atividades, organizadas e orientadas pelo professor para a compreensão de um conceito e dos procedimentos envolvidos. Desta forma, irá ser proporcionado o confronto entre as concepções dos alunos e os conceitos científicos no assunto que está sendo tratado, e a possibilidade também da inserção de temáticas atuais.

Para o ensino de conteúdos abstratos e complexos são necessárias estratégias pedagógicas alternativas que contribuam para um aprendizado mais duradouro ou significativo e não mecânico ou automático. Diante disso, acredita-se que o conhecimento neurocientífico associado à teoria de Ausubel podem se encaixar como um saber importante para complementar a prática pedagógica tradicional e facilitar a aprendizagem significativa de conceitos de Genética.

A partir de levantamento bibliográfico, percebeu-se que ainda não há estudos que abordem a interlocução entre a Neurociência e a Teoria de Aprendizagem Significativa no contexto do ensino. Esta interação é possível porque a teoria de Ausubel é essencialmente cognitiva e, conforme ressalta Kandel et al. (2003, p. 1165), a Neurociência atual é a Neurociência Cognitiva, "um misto de Neurofisiologia, Anatomia, Biologia Desenvolvimentalista, Biologia Celular e Molecular e Psicologia Cognitiva".

A partir do contexto apresentado, este artigo de revisão bibliográfica tem por objetivo associar os conhecimentos neurocientíficos com a Teoria da Aprendizagem Significativa como proposta teórica para facilitar o ensino e aprendizagem significativa de Genética. 


\section{Ensino de Genética}

Nunca se viu uma área do conhecimento avançar tanto quanto a Genética, cujos princípios vêm sendo construídos desde as proposições de Mendel para explicar os mecanismos hereditários em plantas híbridas em 1865, a estrutura molecular do DNA por Watson e Crick em 1953, os mecanismos envolvidos na regulação gênica, as técnicas de DNA recombinante e PCR (reação em cadeia da polimerase) até o desenvolvimento de métodos para sequenciar ácidos nucleicos e proteínas (NUNES, 2010). Dada a sua importância, hoje se observa que muitos dos seus conceitos - DNA, cromossomo, genoma, clonagem, transgênicos, entre outros - ultrapassaram os muros acadêmicos e são discutidos em jornais e revistas de ampla circulação ou em programas de entretenimento veiculados pela tevê ou pelo rádio (BRASIL, 2000).

Nas escolas públicas brasileiras os conteúdos de Genética são ensinados, tradicionalmente, no $3^{\circ}$ ano do Ensino Médio. Entretanto, o seu entendimento pela maioria dos alunos ainda está aquém do esperado, principalmente pelo nível de abstração e complexidade do próprio vocabulário da área, o que acaba levando os alunos a decorar os seus conceitos em vez de compreendê-los, diferenciá-los e relacioná-los com a vida prática (SALIM et al., 2007). Além disso, os constantes avanços da área geram um grande número de informações que nem sempre são publicadas de maneira correta nos livros didáticos destinados ao Ensino Médio no Brasil (VILAS-BOAS, 2006).

Estudos revelam que nem mesmo os conceitos fundamentais de Genética são compreendidos pelos alunos ao final do Ensino Médio, os quais apresentam dificuldades em relacionar gene e cromossomo, compreender a finalidade das divisões celulares por mitose e meiose (SCHEID e FERRARI, 2006), entender o significado e a função das proteínas (CARVALHO et al., 2012), além de demonstrar falta de conhecimentos básicos sobre as estruturas e mecanismos envolvidos na transmissão das informações genéticas (LEWIS e WOOD-ROBINSON, 2000).

Os conceitos básicos de Genética também são mal compreendidos por alunos da própria graduação, desde futuros profissionais da área de saúde (dentistas, fonoaudiólogos, médicos, nutricionistas e psicólogos) até futuros professores de Ciências e Biologia (INFANTE-MALACHIAS et al., 2010). Schneider et al. (2013), a partir da aplicação de um módulo didático, verificaram que os estudantes do curso de Licenciatura em Ciências Biológicas demonstram dificuldade para integrar conceitos científicos (como genes) aos processos biológicos mais complexos. Segundo as pesquisadoras, em decorrência de uma intervenção pedagógica, percebeu-se que os estudantes passaram de uma visão mais determinista - a de que o gene comanda todos os processos metabólicos - para uma visão mais sistêmica, ou seja, de que não são exclusivamente os genes, mas que também há outras moléculas envolvidas, como os promotores e sinalizadores. Entretanto, mesmo em contato com definições alternativas, o conceito molecular clássico de gene ainda foi predominante.

Além da complexidade intrínseca do tema, a forma tradicional de transmissão dos conteúdos de Genética promove o desinteresse e a aprendizagem mecânica ou "decoreba", com o consequente esquecimento e impossibilidade de generalização para outros contextos (CARDOSO et al., 2010). Somado a isto, os 
aprendizagem ainda mais prejudicada (MELO e CARMO, 2009), o que certamente demanda maior acuidade dos docentes na sua seleção.

No Brasil, a literatura científica também aponta que é reduzido o número de publicações voltadas ao ensino de Genética e Biologia Molecular no Ensino Médio, de modo que se tornam fundamentais crescentes investigações acerca das abordagens de ensino destas disciplinas, bem como a publicação dos resultados dessas pesquisas à comunidade escolar e à sociedade em geral (MELO e CARMO, 2009).

Compreender os conceitos básicos de Genética (DNA, cromossomo, gene, mitose, meiose, entre outros) é fundamental para o entendimento das novas tecnologias da área (JUSTINA e FERLA, 2006). A dificuldade de entendimento gera um estado de alienação por parte de um grande número de alunos egressos do Ensino Médio e graduação, os quais não apresentam um entendimento suficiente para posicionar-se em relação às tecnologias emergentes desta área (FREIDENREICH et al., 2011).

Chu e Reid (2012) citam cinco principais fontes de dificuldades em compreender os conceitos de Genética: (1) experiências anteriores negativas com a aprendizagem de conceitos científicos; (2) complexidade do conteúdo; (3) vocabulário ou terminologia difícil; (4) materiais de apoio inseguros; (5) inadequação pedagógica.

A literatura científica ressalta que compreender os conceitos de Genética é difícil porque se trata de um conteúdo complexo que exige muita abstração (KILIÇ e SAGLAM, 2014) e que a dificuldade em compreender conceitos complexos e abstratos está vinculada a problemas no processamento cerebral, como limitações na memória de trabalho (REID, 2009). A memória de trabalho será descrita com maiores detalhes na sequência do texto.

Pode-se dizer que as dificuldades em ensinar e aprender Genética têm sido abundantemente exploradas, porém tem havido pouco interesse no desenvolvimento de estratégias para lidar com elas (KNIPPELS et al. 2005). Por isso, segundo Oliveira et al. (2012, p. 28),

(...) verifica-se a urgente necessidade da disponibilização de novas alternativas metodológicas, a fim de auxiliar o docente a ministrar conteúdos da Genética em sala de aula, melhorar a compreensão e internalização de conceitos fundamentais da disciplina em questão e tornar a Genética uma disciplina mais atraente e interessante.

Experiências bem sucedidas têm sido relatadas por professores que buscam contextualizar o ensino de Genética, pois o aluno torna-se mais interessado quando o assunto é vinculado com questões do seu cotidiano (CAMARGO e INFANTE-MALACHIAS, 2007). Encontram-se nas Diretrizes Curriculares Nacionais da Educação Básica (DCNs) orientações de que o currículo deve ser organizado conforme as características dos estudantes e particularidades do ambiente onde vivem, ou seja, o currículo precisa ser contextualizado, incluindo os componentes obrigatórios e outros "mais flexíveis" que atendam aos interesses, necessidades e características dos alunos (BRASIL, 2013). Assim, o conteúdo de Genética, para ganhar significado, deve ser associado a questões reais da atualidade, como preconceito racial, clonagem terapêutica, cultivos transgênicos, entre outros, de forma que os professores consigam estimular seus alunos a desenvolverem 
competências e habilidades para poder analisar, se posicionar e argumentar diante destas questões éticas, políticas, econômicas, religiosas e morais (BRASIL, 2000).

Os jogos e vídeos educativos, bem como outros instrumentos lúdicos, são importantes ferramentas para complementar o ensino e aprendizagem de Genética, revelando-se como elementos motivadores e facilitadores como bem observaram Oliveira et al. (2012) sobre o uso de vídeos educativos. De igual importância, Braga e Matos (2013) construíram e aplicaram um jogo denominado Kronus, com intuito de trabalhar conteúdos de Biotecnologia e revisar conceitos de Genética com alunos da terceira série do Ensino Médio de uma escola pública. A partir da percepção dos alunos, os pesquisadores observaram e concluíram que esta ferramenta lúdica é importante para despertar o interesse dos alunos pelo conteúdo de Genética, além de promover descontração e diversão.

Estratégias de ensino usando modelagens e sequências didáticas também vêm sendo empregadas com os alunos. Rodrigues (2012) utilizando materiais alternativos (garrafas PET, papelão, alumínio, vidro, massa de modelar, cartolina, isopor, madeira, etc), criaram modelagens didáticas representativas de conteúdos básicos de Genética (síntese de proteínas, duplicação do DNA, divisão celular e núcleo celular) e verificaram, por meio desses recursos, a possibilidade de despertar um maior envolvimento e compreensão do conteúdo proposto. Sousa e Teixeira (2014), por outro lado, desenvolveram e aplicaram uma sequência didática com conteúdos de Genética fundamentada no enfoque Ciência Tecnologia e Sociedade (CTS). Desconsiderando as limitações em relação à implementação da abordagem CTS no ensino público brasileiro, a proposta dos autores contribuiu para otimizar o processo de ensino e aprendizagem de Genética, proporcionando maior participação e interesse dos alunos e melhora na interação entre professores e alunos, além de fornecer informações atualizadas sobre questões de ciência e tecnologia.

Um estudo conduzido por Tsui e Treagust (2004) analisou a aprendizagem conceitual de Genética partindo de uma perspectiva ontológica. Ao longo de um período de seis semanas, o professor ensinou conceitos de Genética e engajou seus alunos em atividades de um programa computacional integrativo, denominado "BioLogica". Os resultados demonstraram pouco sucesso nesta intervenção, pois a maioria dos alunos não adquiriu concepções mais sofisticadas dos conceitos de Genética (por ex.: conceito gene).

Em geral, para o ensino-aprendizagem de conteúdos complexos são necessárias estratégias pedagógicas que contribuam para um aprendizado mais eficiente, pois, conforme as experiências acima descritas, com métodos diferenciados de ensino (modelagens e sequencias didáticas, jogos, vídeos, entre outros), mostraram-se promissoras para serem implementadas no ensino de Genética. Estes instrumentos, além de complementarem a prática de ensino tradicional, permitem uma maior interação entre conhecimento/professor/aluno, trazendo importantes contribuições ao processo de ensino e aprendizagem (MARTINEZ et al. 2008).

\section{Neurociência - aspectos conceituais}


e funcional, vem promovendo um maior entendimento dos mecanismos neurobiológicos subjacentes ao comportamento e cognição, na normalidade ou patologia. As terapias com células-tronco, psicofarmacologia, robótica, técnicas avançadas de neurocirurgia, para citar algumas, buscam incessantemente aperfeiçoar o tratamento de diversas afecções neurológicas que limitam a vida de milhões de pessoas no mundo inteiro, como as doenças de Alzheimer, Parkinson, Esclerose Múltipla, Lesões Medulares, entre outras.

A Neurociência é um campo de estudos e pesquisa relativamente novo, e suas maiores descobertas aconteceram nos últimos 100 anos, quando muitos aspectos da fisiologia, bioquímica, farmacologia e estrutura do cérebro de vertebrados foram compreendidos (GOSWAMI, 2004). Embora estudos mostrem que a preocupação com o estudo do cérebro e suas funções remonta à Antiguidade, incluindo povos egípcios e gregos, foi a partir da última década do século $X X$, denominada década do cérebro, que os maiores progressos neurocientíficos vêm ocorrendo. De fato, desde então, os avanços tecnológicos, em especial as técnicas de neuroimagem estrutural e funcional, permitiram analisar detalhadamente as estruturas cerebrais em pleno funcionamento (CARVALHO, 2011).

A década do cérebro também foi palco do desenvolvimento da Neurociência Cognitiva, uma abordagem funcional do encéfalo constituída por uma combinação de métodos de uma variedade de campos, como Biologia Celular, Neuroimagem, Psicologia Cognitiva, Neurologia Comportamental e Ciência Computacional (KANDEL et al., 2003, p. 382).

Pode-se dizer que a Neurociência Cognitiva teve origem em um esforço científico histórico de várias ciências neurais e comportamentais, como a Psicologia Fisiológica, Neuropsicologia e o próprio termo "Neurociências" (mais amplo que Neuroanatomia e Neurofisiologia). Estes esforços buscaram relacionar estudos dedicados a diversos aspectos do cérebro, que podem ser pensados em três dimensões: (a) vertical: nível de organização estrutural e funcional do cérebro; (b) horizontal: interações entre cérebro, corpo e ambiente dos organismos e (c) temporal: questões filogenéticas e ontogenéticas que determinam a estrutura e funcionamento cerebral (PEREIRA JR, 2011, p. 510).

Com o objetivo de estabelecer relações entre o funcionamento cerebral e as funções cognitivas humanas e animais, a Neurociência Cognitiva utiliza uma variedade de métodos e técnicas, como análises bioquímicas, autópsia, métodos de neuroimagem funcional (tomografia por emissões de pósitrons - PET e ressonância magnética funcional - $f M R I)$, eletroencefalografia (EEG) e magnetoencefalografia (MEG) (GEAKE e COOPER, 2003). Os métodos de neuroimagem funcional proporcionaram um grande avanço na Neurociência Cognitiva ao permitirem aos neurocientistas um estudo do cérebro em pleno funcionamento, gerando um aprofundamento do conhecimento de processos como linguagem, pensamento e raciocínio, leitura e matemática (GOSWAMI, 2004; 2006).

A Neurociência Cognitiva estuda temas como funções perceptivas, cognição espacial, audição e música, emoções, imitação, motricidade, linguagem e consciência, assim como comportamentos cognitivos relevantes para o campo da educação, por exemplo, inteligência, motivação, criatividade, aprendizagem e memória (GOSWAMI, 2004). No entanto, é pertinente neste texto conceituar e detalhar, a partir de uma visão neurocientífica, a aprendizagem e a memória, pois 
são funções cognitivas que interferem diretamente no ensino de Genética, proposta central desta discussão.

Há diversas definições de aprendizagem na literatura científica. Segundo uma delas, aprendizagem é um processo que ocorre quando uma pessoa, em virtude de determinadas experiências, que incluem necessariamente inter-relações com o contexto, produz respostas novas, modifica as existentes, ou quando respostas que se encontram presentes existentes no repertório do indivíduo são emitidas em relação a aspectos novos do contexto (DEL RIO, 1996).

Independente da concepção teórica adotada, a aprendizagem trata-se de um processo neurobiológico, ou seja, se cumpre no sistema nervoso central (SNC), onde são produzidas modificações muitas vezes permanentes que se traduzem em modificações funcionais e comportamentais, as quais permitem uma melhor adaptação do indivíduo no ambiente (ROTTA et al., 2007). Este fenômeno é chamado de plasticidade neural ou neuroplasticidade, uma alteração morfológica e funcional adaptativa do sistema nervoso em resposta às mudanças ambientais, que se estende desde a resposta a lesões no ambiente neural, até as sutis alterações resultantes dos processos de aprendizagem e memória (LENT, 2010). Para Guerra (2011, p.8),

\begin{abstract}
Neuroplasticidade é a propriedade de "fazer e desfazer" conexões entre neurônios. Ela possibilita a reorganização da estrutura do SN e do cérebro e constitui a base biológica da aprendizagem e do esquecimento. Preservamos as sinapses e, portanto, redes neurais relacionadas aos comportamentos essenciais à nossa sobrevivência. Aprendemos o que é significativo e necessário para vivermos bem e esquecemos aquilo que não tem mais relevância para o nosso viver.
\end{abstract}

A aprendizagem depende da integração de muitas funções do sistema nervoso (atenção, as memórias, funções executivas, percepção e emoções, etc.) com o ambiente, que fornece as informações que devem ser processadas pelo indivíduo. A biologia cerebral e o ambiente são fatores entrelaçados quando queremos explicar a aprendizagem (SIQUEIRA e GURGEL-GIANNETTI, 2011).

De uma maneira bastante didática, Siqueira e Gurgel-Giannetti (2011) dividem a aprendizagem em três etapas: entrada (input), processamento e saída (output). $O$ input constitui os processos que ocorrem desde a captação das informações pelos órgãos sensoriais até a percepção das informações pelo cérebro. O processamento ocorre em áreas gnósicas e refere-se à organização, integração e armazenamento de informações. O output, ou resposta efetora, ocorre pelas vias eferentes motoras.

Os conceitos de aprendizagem e memória podem parecer próximos, porém há uma clara distinção entre estes dois processos. De forma geral, aprendizagem é um processo pelo qual os seres humanos e demais animais adquirem informações do ambiente (interno e externo), e memória é o processo pelo qual estas informações são codificadas, armazenadas e posteriormente recuperadas (KANDEL et al., 2003; LENT, 2010).

Por mais de um século a memória e outras funções neurais eram consideradas produtos somente do córtex cerebral. Entretanto, na atualidade, sabe-se que a memória é operada em muitas regiões cerebrais. Além disso, a memória apresenta vários tipos e subtipos diferentes, porém interdependentes (CAMPO-CABAL, 2012). 
As memórias podem ser classificadas quanto ao tempo de retenção em memória ultrarrápida ou imediata, memória de curta duração e memória de longa duração. Na memória ultrarrápida ou memória sensorial, a retenção dura alguns segundos e tem a característica de ser pré-consciente, ou seja, não alcança a consciência. A memória de curta duração ocorre paralelamente com a memória de longa duração e dura poucas horas, garante a continuidade do presente e envolve processos bioquímicos breves no hipocampo e córtex entorrinal. Na memória de longa duração, a retenção perdura por muitas horas, dias ou anos. Sua formação depende de processos moleculares que duram de 3 a 6 horas, os quais ocorrem no hipocampo, núcleos amigdalinos e outras áreas (LENT, 2010; IZQUIERDO et al., 2013).

Em relação ao conteúdo, por exemplo, a memória pode ser dividida em dois grandes grupos: a memória declarativa e a memória não declarativa ou implícita. Esta última engloba as memórias de procedimentos, as quais são capacidades ou habilidades sensoriais e motoras aprendidas previamente e que se tornaram automáticas, como andar de bicicleta, dirigir um carro, usar um teclado. Esta forma específica de memória depende fundamentalmente de circuitos subcorticais que incluem o núcleo caudato e circuitos cerebelares (IZQUIERDO et al., 2013).

A memória declarativa é aquela que popularmente chamamos de "memória". Classifica-se como semântica (conhecimentos gerais) e episódicas e/ou autobiográficas (fatos e eventos). A memória declarativa depende do hipocampo, a amígdala e várias regiões corticais (pré-frontal, parietal entre outras). O hipocampo, presente na região medial dos lobos temporais, é a estrutura cerebral central da formação de memórias declarativas. Integra um circuito que inclui o córtex entorrinal, o núcleo da amígdala e áreas corticais distantes. É classicamente destacado como a estrutura cerebral responsável pelo aprendizado e memória em humanos e roedores (formação da memória declarativa), porém não se caracteriza como um local de armazenamento. As informações duradouras são estocadas em outras regiões do cérebro, e cada região cerebral de processamento complexo armazena informações a partir do comando hipocampal; por exemplo, o córtex ínfero-temporal trata de armazenar arquivos icônicos enquanto que a área de Wernicke no lobo temporal esquerdo armazena informações léxicas e fonéticas (LENT, 2010; IZQUIERDO et al., 2013).

Há um tipo de memória crucial para a aquisição, codificação e armazenamento de qualquer conteúdo ou habilidade: a memória de trabalho ou operacional. Pesquisadores costumam comparar a memória de trabalho com a memória RAM de computadores, em que as informações são mantidas "vivas" por alguns segundos ou minutos, enquanto estão sendo percebidas ou processadas (IZQUIERDO et al., 2013).

A memória de trabalho (working memory) tem a função de permitir a retenção e manipulação temporária das informações para a compreensão dos fatos, raciocínio e resolução de problemas, bem como para o planejamento de ações comportamentais. Utiliza-se esta forma de memória para lembrar número de telefone que acabaram de dizer, informações para uma prova, entre outros (LENT, 2010).

A capacidade de memória de trabalho é limitada, ou seja, o indivíduo não possibilita o resgate das informações apreendidas ou consolidadas na memória de 
longo prazo, com a qual tem a capacidade de conectar as informações novas. Desta forma, toda informação que chega ao cérebro é organizada e processada pela memória de trabalho, por meio da interação com o conhecimento presente na memória de longo prazo (CAMPO-CABAL, 2012).

Em 1974, Baddeley e Hitch dividiram a memória de trabalho em três subsistemas: (1) componente executivo central (regiões pré-frontais do cérebro); (2) componente visuoespacial (lobo parietal inferior e parieto-occipital dorsal); (3) componente fonológico ou alça fonológica (giro supramarginal) (BADDELEY, 2003). Recentemente, Baddeley (2003) propôs um quarto componente, o retentor episódico ou episodic buffer, cuja função seria a de integrar as informações mantidas temporariamente na memória de trabalho com aquelas provenientes dos sistemas de longo prazo.

A capacidade de memória de trabalho se correlaciona com o sucesso acadêmico. Alguns autores afirmam que a dificuldade em compreender conceitos complexos e abstratos está vinculada a problemas no processamento cerebral, como limitações na memória de trabalho (REID, 2009).

Os tipos, subtipos e características das memórias podem ser visualizados no quadro abaixo: 
Quadro 1 - Tipos e características das memórias

\begin{tabular}{|c|c|c|c|}
\hline \multicolumn{4}{|c|}{ Classificação das memórias quanto ao tempo de retenção } \\
\hline \multicolumn{2}{|c|}{ Tempo de retenção } & \multicolumn{2}{|l|}{ Características } \\
\hline \multicolumn{2}{|c|}{ Ultrarrápida ou imediata } & \multicolumn{2}{|c|}{$\begin{array}{l}\text { Dura frações de segundos a alguns segundos; memória } \\
\text { sensorial. }\end{array}$} \\
\hline \multicolumn{2}{|c|}{ Curta duração } & \multicolumn{2}{|c|}{$\begin{array}{l}\text { Dura minutos ou horas, garante o sentido de continuidade } \\
\text { do presente. }\end{array}$} \\
\hline \multicolumn{2}{|c|}{ Longa duração } & \multicolumn{2}{|c|}{$\begin{array}{l}\text { Dura horas, dias ou anos, garante o registro do passado } \\
\text { autobiográfico e dos conhecimentos do indivíduo. }\end{array}$} \\
\hline \multicolumn{4}{|c|}{ Classificação das memórias quanto a sua natureza } \\
\hline Tipos & Subtipos & Características & $\begin{array}{l}\text { Regiões } \\
\text { cerebrais }\end{array}$ \\
\hline \multirow{2}{*}{$\begin{array}{l}\text { Explícita ou declarativa } \\
\text { (pode ser descrita por meio } \\
\text { de palavras e outros } \\
\text { símbolos) }\end{array}$} & Episódica & $\begin{array}{l}\text { Tem uma referência temporal: memória } \\
\text { de fatos sequenciados. }\end{array}$ & \multirow{2}{*}{$\begin{array}{l}\text { Lobo } \\
\text { temporal } \\
\text { medial } \\
\text { Diencéfalo }\end{array}$} \\
\hline & Semântica & $\begin{array}{l}\text { Envolve conceitos atemporais: memória } \\
\text { cultural. }\end{array}$ & \\
\hline \multirow{4}{*}{$\begin{array}{c}\text { Implícita ou não } \\
\text { declarativa (não precisa ser } \\
\text { descrita por meio de } \\
\text { palavras) }\end{array}$} & $\begin{array}{l}\text { De representação } \\
\text { perceptual }\end{array}$ & $\begin{array}{l}\text { Representa imagens sem significado } \\
\text { conhecido: memória pré-consciente. }\end{array}$ & Neocórtex \\
\hline & De procedimentos & Hábitos, habilidades e regras. & $\begin{array}{l}\text { Estriado } \\
\text { Cerebelo }\end{array}$ \\
\hline & Associativa & $\begin{array}{l}\text { Associa dois ou mais estímulos } \\
\text { (condicionamento clássico), ou um } \\
\text { estímulo a certa resposta } \\
\text { (condicionamento operante). }\end{array}$ & $\begin{array}{c}\text { Amígdala } \\
\text { (respostas } \\
\text { emocionais) } \\
\text { Cerebelo } \\
\text { (respostas } \\
\text { musculares } \\
\text { esqueléticas) }\end{array}$ \\
\hline & Não associativa & $\begin{array}{l}\text { Atenua uma resposta (habituação) ou } \\
\text { aumenta-a (sensibilização) através da } \\
\text { repetição de um mesmo estímulo. }\end{array}$ & Vias reflexas \\
\hline \multicolumn{2}{|c|}{ Memória de trabalho } & $\begin{array}{l}\text { Permite o raciocínio e o planejamento do } \\
\text { comportamento. }\end{array}$ & $\begin{array}{l}\text { Córtex pré- } \\
\text { frontal } \\
\text { (componente } \\
\text { executivo) } \\
\text { Córtex } \\
\text { parieto- } \\
\text { occipital }\end{array}$ \\
\hline
\end{tabular}

Fonte: Adaptado de Lent (2010). As informações sobre as regiões cerebrais foram capturadas de Squire e Zola (1996). 
As emoções desempenham um papel importante na aprendizagem e memória. São sentimentos que intensificam a atividade dos circuitos neurais, fortalecendo suas conexões sinápticas, estimulando a aquisição, retenção, consolidação e evocação das informações (CARVALHO, 2011). Quanto mais interessante e importante é a informação, mais fácil sua retenção e evocação. As emoções melhoram significativamente a memória declarativa. É possível notar que as pessoas têm maior facilidade de recordar fatos ou eventos acompanhados de emoções, sejam positivas ou negativas (DALMAZ e NETTO, 2004).

Segundo a literatura neurocientífica, as reações emocionais apresentam manifestações subjetivas, comportamentais e fisiológicas. As manifestações subjetivas referem-se ao sentimento consciente de prazer ou desprazer despertado pelas emoções. As manifestações comportamentais são ações motoras involuntárias ou reflexas (gritos de susto ou alegria) ou voluntárias (correr, pular etc). As manifestações fisiológicas envolvem respostas corporais, como taquicardia, hiperventilação, rosto corado, sensação de aperto no peito. Estas reações, em conjunto, são produto do funcionamento do sistema límbico, um conjunto de estruturas localizadas na face medial dos hemisférios cerebrais e diencéfalo, e incluem áreas como o giro cingulado, hipotálamo, amígdala, núcleos do tálamo, córtex pré-frontal (LENT, 2010). Segundo Guerra (2011), os neurônios de áreas límbicas mantêm fortes conexões com neurônios de áreas importantes para formação de memórias.

Entretanto, mesmo as informações bem estabelecidas e consolidadas, ou seja, aprendidas significativamente, não são permanentes. É comum ocorrer o esquecimento, um fenômeno fisiológico natural e essencial ao bom funcionamento da memória, que ocorre continuamente enfraquecendo os padrões mnemônicos aprendidos (DALMAZ e NETTO, 2004).

Como ressaltado anteriormente, a aprendizagem pode ser entendida como o produto da interação dinâmica entre o funcionamento cerebral e o ambiente. Desta forma, fatores ambientais como o contexto familiar e escolar, aspectos culturais, econômicos, entre outros, interferem significativamente na aprendizagem. Os aprendizes com carência nutricional, privados de material escolar adequado, estimulação e incentivo dos pais e professores, com problemas psiquiátricos (depressão, ansiedade, etc.), podem apresentar dificuldades de aprendizagem . Considerando a etiologia multifatorial dos problemas de aprendizagem, o tratamento de uma dificuldade específica é necessariamente multidisciplinar (GUERRA, 2011).

\section{Aprendizagem Significativa}

Existem várias teorias da aprendizagem. Entre as principais, podem-se distinguir dois grandes blocos: (1) as teorias associacionistas ou de condicionamento, as quais são compostas por duas correntes: (a) condicionamento clássico e (b) condicionamento operante; (2) as teorias mediacionais, compostas pelas seguintes correntes: (a) aprendizagem social; (b) 
teoria cognitiva e (c) teoria do processamento de informação (PÉREZ GOMÉZ, 2000).

A Teoria da Aprendizagem Significativa é uma teoria cognitiva. Foi desenvolvida por David Ausubel na década de 60, do século passado. Um dos seus pontos centrais é que a variável que mais influencia a aprendizagem de novos conhecimentos são os conhecimentos que o aluno já possui e que servem como ponto de partida para novas aprendizagens. Dito em outras palavras, o ser humano aprende a partir daquilo que já sabe (MOREIRA e SPERLING, 2009). Nas palavras do próprio Ausubel:

Se eu tivesse que reduzir toda a psicologia educacional a um único princípio, diria isto: o fator singular que mais influencia a aprendizagem é aquilo que o aprendiz já conhece. Descubra isso e ensine-o de acordo. (AUSUBEL et al., 1980, p. 137).

Os conhecimentos que o aluno já possui em sua estrutura cognitiva são definidos por Ausubel como conceitos subsunçores ou simplesmente subsunçores, que funcionam como uma âncora ou ponte cognitiva para a aquisição de novos conhecimentos (MOREIRA, 2012).

A aprendizagem significativa ocorre quando as novas informações interagem de maneira substantiva e não arbitrária com aquilo que o aprendiz já sabe. A terminologia "substantiva" quer dizer não literal, ou não ao "pé da letra", e não arbitrária significa que a interação não ocorre com qualquer ideia, mas com conhecimentos especificamente relevantes pré-existentes na estrutura cognitiva do indivíduo (MOREIRA, 2012).

Uma importante condição para que ocorra a aprendizagem significativa é a intencionalidade, ou seja, a vontade de aprender. Desta forma, pode-se dizer que o aprendiz é um sujeito ativo no processo de aprendizagem e pode decidir a maneira como quer assimilar os conteúdos. A motivação, entusiasmo, curiosidade e envolvimento do aprendiz são considerados emoções positivas e são fundamentais para o aprendizado significativo (TAVARES, 2008; MOREIRA, 2012).

Durante a aprendizagem significativa, o aprendiz consegue transformar o significado lógico do material pedagógico em significado psicológico, articulando o conteúdo da aprendizagem de maneira peculiar em sua estrutura cognitiva. As pessoas podem aprender significativamente um mesmo conteúdo, porém desenvolvem opiniões distintas sobre ele em função da construção singular do conhecimento (TAVARES, 2008; TAVARES, 2010).

Basicamente, existem três formas de aprendizagem significativa: representacional, de conceitos e proposicional. A aprendizagem representacional é a forma mais elementar de aprendizagem significativa e envolve o aprendizado de símbolos (por exemplo, sílabas ou palavras). Na aprendizagem conceitual, o indivíduo realiza abstrações acerca dos atributos essenciais dos referentes (eventos, objetos, etc.) e, na aprendizagem proposicional, aprende o significado das ideias expressas no formato de proposições ou sentenças (MOREIRA, 1999).

A teoria da aprendizagem significativa explica o processo de aquisição e organização das informações na estrutura cognitiva da seguinte maneira: uma nova informação potencialmente significativa (a) é assimilada e relacionada a um conceito mais geral ou subsunçor $(A)$ presente na estrutura cognitiva do indivíduo, 
e tanto a nova informação quanto o subsunçor são modificados por esta interação, formando um subsunçor modificado representado por "a, A" (MOREIRA, 1999).

Uma das questões centrais na teoria de Ausubel é a distinção entre aprendizagem mecânica (ou memorística) e aprendizagem significativa. A aprendizagem significativa ocorre quando o aluno interpreta, incorpora e relaciona as novas informações com o conhecimento pré-existente em sua estrutura cognitiva, sendo capaz de aplicar as novas informações para resolver problemas em contextos diferentes (GONZÁLES et al., 2008).

$\mathrm{Na}$ aprendizagem mecânica, muito utilizada pelos alunos e conhecida pelos professores, o aprendiz simplesmente memoriza as informações literalmente, de forma não substantiva, sem atribuir significado, sem compreensão, mas com a capacidade de aplicá-las em situações conhecidas, como provas escolares, porém com rápida retenção. Corresponde ao ensino tradicional, em que o professor apresenta a matéria no quadro, o aluno copia, memoriza para o exame e esquece posteriormente (MOREIRA e SPERLING, 2009). Ou seja, há pouca ou nenhuma integração do novo conhecimento (a) com o conhecimento prévio (A), resultando em duas consequências negativas: primeiro, o conhecimento aprendido mecanicamente, se não for repetido, tende a ser esquecido rapidamente; segundo, na aprendizagem mecânica não acontece modificação da estrutura cognitiva do aprendiz, de modo que o conhecimento obtido tem pouco ou nenhum potencial de ser usado em resolução de problemas futuros (NOVAK e CAÑAS, 2010).

Contudo, é importante lembrar que a aprendizagem significativa e mecânica não são dicotômicas. Elas estão ao longo do mesmo continuum, e grande parte da aprendizagem ocorre na zona intermediária deste contínuo, ou seja, não é totalmente significativa nem inteiramente mecânica (MOREIRA e SPERLING, 2009).

Ausubel também criou o conceito de organizadores prévios, definidos como recursos materiais introdutórios que fazem uma "ponte cognitiva" entre aquilo que o indivíduo sabe e o que precisa aprender. Esta estratégia busca manipular a estrutura cognitiva, facilitando o desenvolvimento de conceitos subsunçores e consequentemente a aprendizagem significativa (MOREIRA, 1999).

Em meados da década de 70, Novak e colaboradores criaram os mapas conceituais, que são ferramentas gráficas utilizadas para a organização e representação hierárquica do conhecimento (NOVAK e CAÑAS, 2010). Os mapas conceituais auxiliam na condução do aprendiz à aprendizagem significativa, por isso têm sido utilizados como estratégia pedagógica para o ensino de diversos temas, possibilitando que conceitos sejam ensinados através do estabelecimento de relações entre eles (FREITAS FILHO, 2007). Além disso, os mapas conceituais ajudam como organizador curricular, disciplinar ou temático, assim como um instrumento avaliativo (SOUZA e BORUCHOVITCH, 2010; CORREIA et al. 2010).

Em resumo, a aprendizagem significativa envolve a aquisição de significados, compreensão do conteúdo aprendido com possibilidade de explicação e transferência para outros contextos ou situações novas, assim como um período de retenção na estrutura cognitiva consideravelmente maior se comparado à aprendizagem mecânica (MOREIRA e SPERLING, 2009; MOREIRA, 2012). 


\section{Neurociência e Aprendizagem Significativa: é possível uma interlocução?}

É bastante provável que Ausubel não tenha se preocupado com questões neurocientíficas quando elaborou sua teoria. No entanto, ele faz uma profunda declaração neurobiológica quando destaca a importância dos conhecimentos prévios como ponto de partida para novas aprendizagens. A partir disto, a teoria de Ausubel nos conduz a pensar que o fator mais importante na aprendizagem são as redes neurais existentes no cérebro do indivíduo. Assim, quando o professor descobre o que seus alunos já sabem, também estará descobrindo as características de suas redes neuronais, e ficará mais fácil para os alunos adquirirem conhecimentos novos (ZULL, 2002).

A respeito dos conhecimentos prévios, Zull (2002) desenvolveu três ideias importantes, a saber: (1) o conhecimento prévio é um fato, ou seja, todos os alunos têm; (2) o conhecimento prévio é persistente porque as conexões neurais são fortes; (3) o conhecimento prévio é o ponto de partida para novos conhecimentos.

As redes neurais ativadas durante o processo de aprendizagem significativa passam por modificações, formando novas sinapses e/ou conexões funcionais com novos neurônios, permitindo a neuroplasticidade, descrita anteriormente. Com o acréscimo contínuo de novas informações relevantes às informações na estrutura cognitiva, a qualidade e extensão das conexões neurais também se intensificam (NOVAK, 2010).

É importante ressaltar que a retenção das informações aprendidas mecanicamente também ocorre na memória de longo prazo (NOVAK e CAÑAS, 2010). Entretanto, a aprendizagem significativa necessita de um processo de retenção mais duradouro na memória de longo prazo, realizado pelo hipocampo e outras estruturas cerebrais descritas anteriormente. E mais, recentes estudos neurocientíficos sustentam a ideia central da teoria de Ausubel de que o conhecimento armazenado durante o aprendizado significativo é organizado no cérebro de forma diferente do conhecimento da proveniente da aprendizagem mecânica (NOVAK, 2011).

A aprendizagem mecânica, apesar de apresentar um tempo de retenção menor, ativa uma rede neural complexa e distribuída em diversas áreas encefálicas, como córtex pré-frontal inferior esquerdo, área motora suplementar, córtex parietal posterior bilateral, cerebelo lateral e lobo temporal medial, incluindo o hipocampo (ROCHE et al., 2009). Levando em consideração estas afirmações, parece provável que muitas informações provenientes da aprendizagem mecânica ficam retidas na memória de curto prazo e na memória de trabalho.

A memória de trabalho tem íntima relação com a aquisição de informações potencialmente significativas. Em um estudo com 21 estudantes do primeiro ano do Ensino Médio, García-Madruga e Fernández-Corte (1999) observaram que a capacidade de memória de trabalho desempenha um papel crucial com o processo de aprendizagem significativa de conhecimentos históricos apresentados. Os organizadores prévios, descritos anteriormente, facilitam a aprendizagem significativa porque aumentam a eficácia de codificação da memória de trabalho e organização da memória de longo prazo (DEHN, 2008). 
Figura 1 - Ilustração da hipotética estrutura da memória de três níveis hierárquicos.

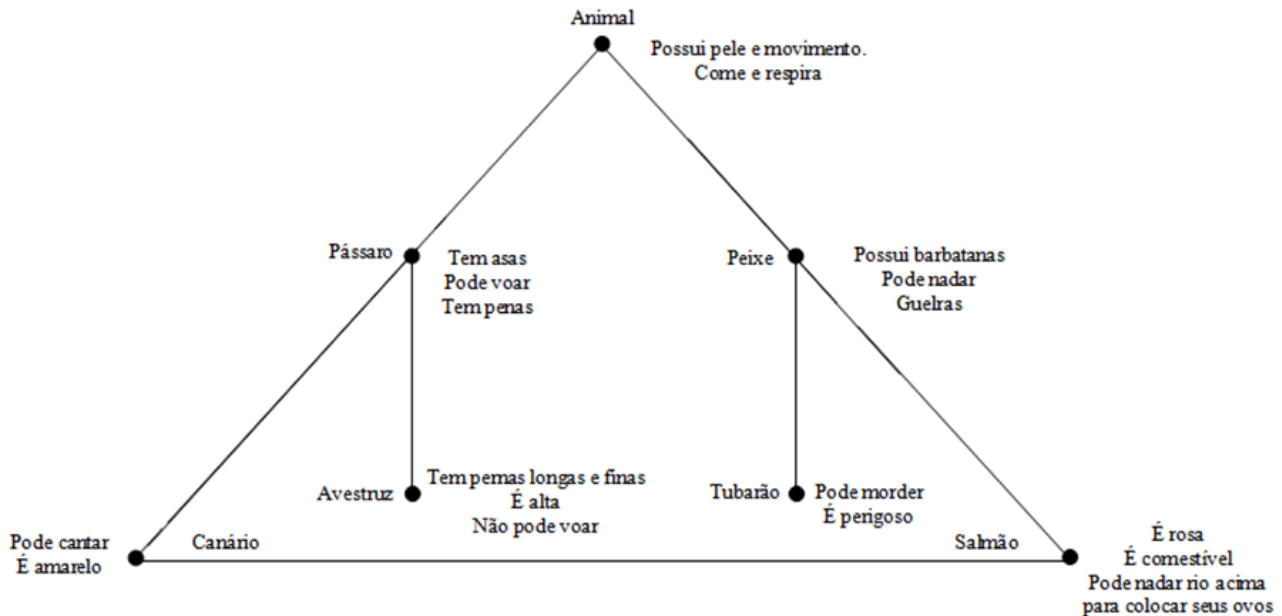

Fonte: Collins e Quillian (1969).

Conforme este modelo, as informações presentes na memória semântica não estão armazenadas de maneira aleatória, mas sim organizadas em níveis hierárquicos. Segundo Mello (2008), os conceitos estão conectados entre si por relações de subordinação ou superordenação, em relações de categoria, funcionando assim como "nós" ou "nodos" em complexas redes semânticas. Quando o indivíduo acessa conscientemente uma informação contida em um destes nodos, desencadeia uma ativação automática de outros conceitos com os quais compartilha propriedades de significado, sendo que a eficácia da ativação depende da força de associação dos nós, determinada pela quantidade de propriedades que as representações têm em comum e na distância entre elas.

Desta forma, usando a Figura 1 como exemplo, se aquilo que foi armazenado com a palavra "canário" foram as frases "pode cantar" e "é amarelo", então se tem um nodo para pássaro (nome da categoria), e nodos para duas propriedades, isto é, "é amarelo" e "pode cantar". As informações sobre pássaros em geral (podem voar, tem asas e penas), situadas em um nível hierárquico superior, não precisam ser armazenadas a cada tipo de pássaro memorizado (COLLINS e QUILLIAN, 1969).

Este modelo elaborado por Collins e Quillian (1969) também permite fazer predições acerca de como as informações são recuperadas na memória humana. Mais uma vez considerando a Figura 1, para opinar se a afirmação "um canário pode cantar" é verdadeira, uma pessoa precisa apenas iniciar no nodo "canário" e recuperar as propriedades armazenadas. Além disso, para opinar sobre "um canário pode voar", a pessoa precisa mover-se para um nível hierárquico acima (categoria pássaro) para recuperar tal propriedade (COLLINS e QUILLIAN, 1969).

A estruturação hierárquica da memória humana assemelha-se ao conceito de mapa conceitual, cuja estrutura apresenta uma nítida semelhança com a fisiologia macroscópica neocortical . De fato, o cérebro humano apresenta aglomerações hierárquicas de neurônios da memória, que crescem e aumentam durante toda a vida e podem ser graficamente representados em mapas conceituais (BALEY, 2005).

Baley (2005), utilizando Hawkins (2004) como referência, afirma que o neocórtex apresenta quatro atributos principais que podem contribuir para 
elucidar os mecanismos biofísicos subjacentes ao mapeamento conceitual, a saber:

1.O neocórtex armazena padrões mnemônicos em sequência, e o processo de recordação ocorre da mesma maneira. A sequência é o bloco de construção da memória humana. Os indivíduos costumam lembrar padrões mnemônicos (alfabeto, discursos, filmes, músicas, conceitos, entre outros) na ordem em que foram armazenados. Desta forma, evocar elementos a partir do meio de uma sequência ou de forma inversa é mais complicado. Ex: evocar padrões como o alfabeto, números de telefone entre outros, ao contrário é bastante difícil. É possível recitar o alfabeto de $\mathrm{A}$ a $\mathrm{Z}$ com muito pouco esforço porque memorizamos a sequência desde o início até o fim.

2.0 neocórtex recorda padrões mnemônicos de maneira autoassociativa. O termo autoassociativa significa que os padrões mnemônicos estão associados com eles mesmos. Em um sistema de memória autoassociativo, uma pessoa pode recordar padrões completos quando em contato com elementos sensoriais em partes ou distorcidos, em que as pessoas visualizam partes de um objeto e conseguem identificá-lo completamente, preenchendo mentalmente o restante. Ex.: uma pessoa está vendo parte de outra atrás de um arbusto; os olhos só veem partes do corpo, porém o cérebro preenche o resto, criando uma percepção da pessoa como um todo.

3.0 neocórtex armazena padrões mnemônicos de forma invariante. Esta é uma característica que marcadamente distingue a memória humana da memória computacional. Esta última armazena dados em perfeita fidelidade, ou seja, exatamente como foram apresentados. Por isso, quando um programa da internet é baixado, cada byte precisa ser copiado com 100 por cento de fidelidade, e um único erro inutiliza o programa. Os padrões mnemônicos armazenados no neocórtex são mais flexíveis, não estão em completa fidelidade, e o indivíduo não consegue lembrar exatamente aquilo que viu, sentiu ou ouviu. $O$ cérebro humano recorda as relações, independente dos detalhes, o que é uma vantagem. Assim, se um indivíduo está familiarizado com um determinado objeto ou pessoa, certamente não terá dificuldades em reconhecê-los a partir de diferentes ângulos, momentos ou contextos.

4.0 neocórtex armazena padrões de forma hierárquica. Hawkins desenvolveu um modelo computacional de aprendizagem e memória chamado Memória Temporal Hierárquica (HTM), para explicar o padrão hierárquico de armazenamento do neocórtex. O termo hierarquia não descreve relações de poder, mas sim o padrão de conectividade no interior e entre as seis camadas celulares do neocórtex. As informações provenientes dos sentidos (visão, tato, audição, etc.), ou inputs sensoriais, entram pelos níveis mais baixos da hierarquia e viajam através das redes neurais buscando células de memória associativas específicas, como mostra a ilustração abaixo (Figura 2). De acordo com o modelo HTM, os "padrões mais simples" aprendidos em níveis inferiores da hierarquia combinam-se com "padrões mais elaborados" armazenados em níveis hierárquicos mais altos. Assim, por exemplo, para aprender novas palavras não é necessário aprender o alfabeto, ou para aprender novas frases de uma canção não é necessário aprender as palavras que a compõem. 
Figura 2 - Modelo HTM do neocórtex. Este modelo apresenta de forma simplificada a conectividade hierárquica das regiões neocorticais em feedback. Os retângulos indicam sequências de padrões mnemônicos aprendidos.

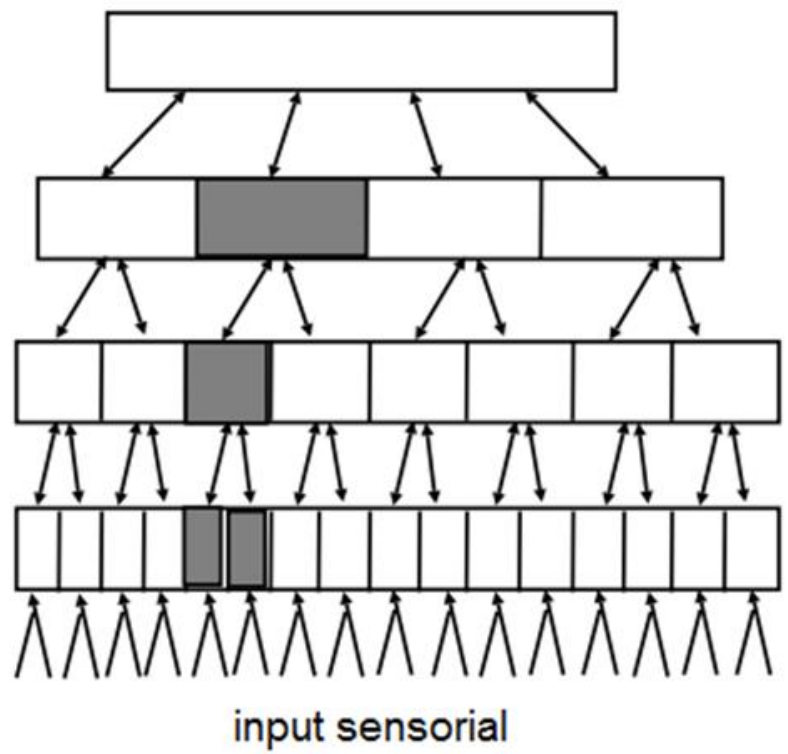

Fonte: Hawkins (2004).

A estrutura cognitiva é um dos conceitos centrais da Teoria da Aprendizagem Significativa. $O$ atual conhecimento das bases neurais da aprendizagem e cognição, o desenvolvimento das técnicas de neuroimagem e os modelos computacionais do comportamento cerebral permitem afirmar que há uma relativa concordância entre a fisiologia cerebral com o conceito de estrutura cognitiva proposto por Ausubel e outras teorias cognitivas. A estrutura cognitiva, do ponto de vista neurocientífico, é um tipo de rede neural, cujo conjunto de células neurais se encontra as ideias ou conceitos, porém não se apresentam organizados de forma hierárquica, como postula a Teoria da Aprendizagem Significativa (PANIAGUA e VILLAGRÁ, 2008).

\section{Neurociência e Aprendizagem Significativa: uma abordagem neurocognitiva para o ensino de Genética}

A Neurociência associada à Teoria da Aprendizagem Significativa proporciona uma abordagem neurocognitiva do processo de ensino-aprendizagem, oferecendo subsídios teóricos e práticos importantes para o trabalho docente, podendo facilitar a aprendizagem significativa em diversos campos com conteúdos abstratos e complexos, como os da Genética.

Isoladamente, a literatura mostra que a Teoria da Aprendizagem Significativa vem sendo utilizada com bastante sucesso no ensino de Ciências (LEMOS e MOREIRA, 2011; NÚÑEZ et al. 2011; NASCIMENTO e MANSO, 2011). O conhecimento neurocientífico, ao contrário, apresenta um status menos satisfatório quanto a sua aplicação direta em sala de aula. Contudo, é possível estabelecer várias relações entre Neurociência e ensino de Ciências, incluindo a formação de professores com o conhecimento da Neurociência, bem como de 
pesquisadores preocupados com a produção de conhecimento neurocientífico destinado aos profissionais do ensino e educação (ANSARI e COCH, 2006).

É importante ressaltar que diversos autores incentivam a utilização do conhecimento neurocientífico no âmbito de ensino (CONSENZA e GUERRA, 2011; CARVALHO, 2011; GUERRA, 2011), porém, a partir de um levantamento bibliográfico, percebeu-se que são raros os estudos que visam à aplicação deste conhecimento em sala de aula. Na verdade, encontrou-se somente o estudo de Silva (2012), cuja dissertação descreve os resultados da aplicação de um Programa de Neurociência em alunos do 3음 ano do Ensino Fundamental. De acordo com os resultados desta dissertação, o referido programa melhorou a prática educativa e estimulou positivamente as áreas cerebrais implicadas nos processos de leitura e escrita (SILVA, 2012).

Conhecer os aspectos neurobiológicos implicados no processo de ensinoaprendizagem pode ajudar os educadores, professores e até mesmo os pais a entenderem melhor como ocorre a aprendizagem, a origem e desenvolvimento dos problemas de aprendizagem, assim como inspirar práticas educacionais (GUERRA, 2011). Contudo, como salienta a autora, apesar do otimismo em relação às contribuições da Neurociência para o ensino e educação, esta não busca trazer a solução para todos os problemas nem propor uma nova pedagogia, mas fundamenta a prática pedagógica que já se realiza, demonstrando que estratégias pedagógicas que respeitam a forma como o cérebro funciona tendem a ser mais eficientes (GUERRA, 2011).

Apesar da importância para os educadores, os conhecimentos neurocientíficos têm sido apresentados de forma superficial e desconectados do seu vínculo com esta área. A produção literária nacional mostra uma escassez de estudos das relações entre mente/cérebro e educação, os livros e materiais disponíveis são poucos, e aqueles que oferecem informações especializadas destinam-se a um grupo seleto de profissionais, como médicos e psicólogos, afastando-se das atividades do professor (CARVALHO, 2011). Além disso, temas neurocientíficos são pouco ou não inseridos na formação inicial do educador, cuja formação é fundamentalmente humanista, essencial para compreensão de vários aspectos envolvidos no ensino e aprendizagem, porém insuficiente diante da complexidade que envolve estes fatores (CONSENZA e GUERRA, 2011).

Destaca-se que a Neurociência proporciona ao professor o conhecimento dos mecanismos neuropsicológicos da memória, do esquecimento, do sono, da atenção, do medo, do humor, da afetividade, dos sentidos, da linguagem, do pensamento, do desenvolvimento neuropsicomotor, assim como sobre o fato de que uma boa prática de ensino pode ser prejudicada por fatores ligados ao cérebro, como ansiedade para aprender, déficits de atenção e pobre reconhecimento de pistas sociais. Contudo, pesquisadores alertam para a questão da disseminação de informações equivocadas sobre o cérebro ou "neuromitos", como, por exemplo, afirmações de que "usamos somente $10 \%$ da capacidade do cérebro" ou "o lado esquerdo do cérebro é responsável pela linguagem e do lado direito para o pensamento abstrato" ou mitos comportamentais como "os disléxicos enxergam as letras inversamente", entre outros. Os neuromitos obscurecem e violam os resultados de pesquisas científicas e podem conduzir a pesquisas defeituosas (CHRISTODOULOU e GAAB, 2009; GOSWAMI, 2006). 
Passando especificamente ao conteúdo de Genética, pode-se afirmar que tem havido o desenvolvimento de poucas estratégias para lidar com as dificuldades impostas pela área (KNIPPELS et al. 2005). Buscando superar problemas como natureza abstrata e complexidade do conteúdo de Genética, Knippels et al. (2005) desenvolveram uma estratégia de ensino fundamentada em quatro critérios:

O ensino de Genética precisa ser sequenciado, ou seja, iniciando-se ao nível mais fundamental do organismo e prosseguindo gradualmente para níveis mais específicos, como o nível celular.

É fundamental explicitar as conexões entre meiose e herança genética.

É preciso fazer a distinção entre células somáticas e gaméticas dentro do contexto do ciclo de vida.

Os alunos devem explorar ativamente as relações entre os níveis de organização biológica do organismo.

Os estudantes tendem a aprender conceitos de Genética mecanicamente ou por "decoreba" e não realizam inter-relações com as situações do cotidiano. Utilizando testes de raciocínio formal (Test of Logical Thinking), orientação para aprendizagem (Learning Approach Questionnaire) e entendimento de conceitos básicos de Genética (Two-tier Genetics Concepts Test), pesquisadores verificaram que estudantes com habilidades de raciocínio mais elaboradas e orientação para aprendizagem significativa apresentam melhor compreensão de conceitos de Genética que alunos com baixa capacidade de raciocínio e orientação para aprendizagem mecânica. Os pesquisadores sugerem que os alunos precisam ser orientados a adotar uma orientação para a aprendizagem significativa e encorajados a realizar conexões entre os conhecimentos prévios e novos, bem como acreditam que a compreensão de Genética pode ser melhorada com uma ampliação da capacidade de raciocínio dos alunos (KILIÇ e SAGLAM, 2014). Segundo Tavares (2010, p.6-7):

\footnotetext{
Um aprendiz que tenha conhecimentos prévios sobre as características de mamíferos terrestres usará esses atributos quando se deparar com novas informações sobre mamíferos aquáticos. Esses conhecimentos (sangue quente, respiração através do oxigênio gasoso, gestação interna e etc.) auxiliarão a entender o comportamento dos mamíferos aquáticos, servirão como âncora na aquisição do novo conhecimento. Na interação entre o conhecimento novo e o conhecimento antigo ambos serão modificados de uma maneira específica por cada aprendiz, como consequência de uma estrutura cognitiva peculiar a cada pessoa. Depois do aprendizado sobre mamíferos aquáticos, o aprendiz terá uma concepção mais inclusiva sobre os mamíferos, onde antes só existiam os terrestres.
}

Como dito anteriormente, para que ocorra aprendizagem significativa, o estudante precisa estar disposto e motivado a aprender (MOREIRA, 1999). O professor, por meio de sua ação profissional, pode transmitir estímulos que favoreçam a neuroplasticidade e secreção de hormônios que provocam o entusiasmo e o desejo de aprender ou o extremo oposto, o desinteresse (CARVALHO, 2011). Pensando nisso, o professor precisa transformar o conteúdo programático de Genética em algo relevante e motivador para o aprendiz, ou seja, a configuração de um cotidiano escolar que ofereça interesse e motivação, os quais são requisitos necessários para qualquer tipo de aprendizado É importante 
lembrar que os adolescentes aprendem o que os motiva, o que os emociona, o que desejam, aquilo que tem significado para seu cotidiano (GUERRA, 2011).

Pensando em aspectos relativos à socialização, o professor pode promover desafios e competições entre os alunos, incentivar os trabalhos em grupo, seguidos de apresentação, que adicionalmente favorece o desenvolvimento das habilidades sociais. É necessário evitar exposições prolongadas do conteúdo, pois a atenção não se mantém por longos períodos, e inserir intervalos ou mudanças de atividades são fundamentais (GUERRA, 2011).

Recursos que explorem os canais multissensoriais, devidamente fundamentados no conhecimento neurocientífico, podem facilitar manutenção da atenção, motivação, facilitando a aprendizagem significativa de Genética. Estes recursos aumentam o acesso de informações ao cérebro, bem como ativam múltiplas redes neurais que estabelecerão associação entre si (GUERRA, 2011). Desta forma, o professor pode utilizar informações verbais, visuais, auditivas e táteis, através de recursos como textos, artigos científicos, imagens, músicas, internet, jogos educativos, objetos virtuais de aprendizagem, mapas conceituais, práticas que envolvam o corpo, bem como a construção e manipulação de modelos didáticos do conteúdo de Genética (mitose e meiose, DNA, RNA, gene, cromossomos e proteínas). Segundo Consenza e Guerra (2011, p.73)

\begin{abstract}
As gerações mais antigas aprendiam principalmente por meio dos textos escritos, mas os jovens atualmente têm sua disposição uma imensa parafernália de material multimídia, principalmente através da internet, o que é muito bom, uma vez que há a oportunidade de se construir uma rede neuronal mais complexa. Neste caso, talvez o papel mais importante do professor seja auxiliar na seleção e orientação, para a exclusão das muitas informações pouco confiáveis ou irrelevantes.
\end{abstract}

A literatura mostra que a memória de trabalho tem um papel importante no processo de aquisição de informações potencialmente significativas. Em um estudo recente, Chu e Reid (2012) observaram que a sobrecarga da memória de trabalho está intimamente relacionada ao desempenho inferior dos alunos em compreender os conceitos de Genética. De acordo com estes pesquisadores, não se trata da quantidade de informação envolvida, mas sim de quantos conceitos e/ou ideias precisam ser retidos e processados simultaneamente a fim de ganhar a compreensão de cada assunto ou tema (CHU e REID, 2012).

Levando em conta estas informações, o professor deve buscar meios de minimizar a sobrecarga mental dos seus alunos, como, por exemplo, através da criação de momentos para descontração e descanso (contar piadas, ouvir música, entre outros), que, além de facilitar a atenção, promovem uma higiene mental, importante para evitar a sobrecarga da memória de trabalho (CONSENZA e GUERRA, 2011).

Os estímulos verbais (palavras, conceitos, textos) e imagéticos (figuras, arranjos espaciais, cores) podem ser processados simultaneamente na memória de trabalho, sem causar sobrecarga. Desta forma, a utilização de organizadores gráficos, como esquemas, fluxogramas, cronogramas e mapas conceituais pode potencializar a aprendizagem significativa de conceitos de Genética (AGUIAR e CORREIA, 2013). Assim também a estratégia de mapeamento conceitual, pois foi observado que esta técnica contribuiu para reduzir os níveis de ansiedade e atitude negativa de estudantes de Biologia em relação a conceitos de Genética e Ecologia, 
áreas tradicionalmente temidas pelos alunos do Ensino Médio e Superior (OKEBUKOLA e JEGEDE, 1989).

Como visto anteriormente, contextualizar o assunto de Genética é fundamental, uma vez que os alunos dificilmente prestarão atenção em informações que não tenham relações com seu cotidiano, observando-se que o cérebro seleciona as informações mais importantes para o bem-estar e sobrevivência do indivíduo (GUERRA, 2011). Conforme Consenza e Guerra (2011, p. 48):

Terá mais chance de ser significante aquilo que tenha ligações com o que já é conhecido, que atenda a expectativas ou que seja estimulante e agradável. Uma exposição prévia do assunto a ser aprendido, que faça ligações do seu conteúdo com o cotidiano do aprendiz e que crie as expectativas adequadas é uma boa forma de atingir esse objetivo.

A compreensão da neuroplasticidade adaptativa permite que os educadores criem situações de aprendizagem que fortaleçam determinados circuitos neurais e evitem condições de aprendizagem errôneas. A repetição é fundamental para uma aprendizagem significativa e, do ponto de vista neurocientífico, os circuitos neurais ativados repetitivamente e em sincronia tornam-se mais eficientes. Isto se traduz no fato de que os estudantes de música que a praticam têm um desempenho superior, e aquelas sequências de movimentos (dedos e corporais) se tornam automáticas. Estratégias simples visando o reforço de circuitos neurais podem ser utilizadas em estágios de introdução de novos tópicos e fornecer pistas de soluções às questões, evitando que os alunos obtenham respostas erradas, podem reforçar circuitos neurais para um aprendizado eficiente. Em crianças ou mesmo adolescentes, períodos de jogos livres ou dirigidos podem ser uma estratégia bastante eficaz para gerar relações com o material de aprendizagem antes da introdução de conceitos mais formais (GEAKE e COOPER, 2003).

Diante do contexto apresentado, pode-se seguramente afirmar que os conhecimentos neurocientíficos podem ser perfeitamente associados à Teoria da Aprendizagem Significativa, e esta interação, além de possibilitar uma maior compreensão dos processos neurocognitivos envolvidos no ensino e aprendizagem, pode facilitar a aprendizagem significativa de Genética. A partir do conhecimento dos mecanismos neurocognitivos implicados à aprendizagem, comportamento e emoções, funcionamento cerebral e das diferentes estruturas neurais implicadas na aprendizagem, os docentes podem desenvolver estratégias de ensino que amplifiquem a motivação dos alunos para aprender, tornando a atividade de ensinar ainda mais prazerosa (CARVALHO, 2011).

\section{Considerações Finais}

Este artigo, de revisão bibliográfica, teve por objetivo articular os conhecimentos neurocientíficos com a teoria cognitivista de Ausubel como proposta teórica para facilitar a aprendizagem significativa de Genética. Esta interação é perfeitamente possível, pois, como visto, a Neurociência atual é a Neurociência Cognitiva, composta por um conjunto variado de disciplinas que inclui teorias cognitivas. Além disso, os conceitos centrais da teoria de Ausubel 
significativa, mapas conceituais) apresentam um forte correlato neurofisiológico, aumentando a possibilidade desta interlocução.

A Neurociência e a Teoria da Aprendizagem Significativa formam uma abordagem neurocognitiva, e esta interação pode oferecer subsídios teóricos e práticos importantes para o trabalho docente, possibilitando uma melhor compreensão dos processos neurocognitivos envolvidos no ensino-aprendizagem, facilitando a aprendizagem significativa em diversos campos, inclusive na Genética.

Reconhecemos as lacunas deixadas ao longo do texto em relação às questões epistemológicas subjacentes, ao nos reportarmos, por exemplo, à problemática da aprendizagem mecânica, que está relacionada a uma perspectiva epistemológica positivista e que remente a práticas pedagógicas descontextualizadas e que não consideram os conhecimentos prévios e nem o contexto sócio cultural dos alunos. Essa postura epistemológica é fortemente questionada pela epistemologia contemporânea (BACHELARD, 1978, 1996, 1982; KUHN, 2000; FLECK, 2010, 2012, entre outros) e cujos pressupostos vêm sendo apropriados pelos pesquisadores da área de Ensino de Ciências, que buscam estratégias para desmistificar, retificar ou possibilitar o entendimento dos alunos acerca do processo de construção do conhecimento científico.

Desse modo, concordamos com Delizoicov et al. (2002) de que é importante a apropriação do conhecimento epistemológico contemporâneo, aceito pela comunidade de pesquisadores, no contexto do ensino dos conceitos científicos na sala de aula, de modo que os alunos passem a conceber que o processo de produção do conhecimento científico e tecnológico constitui uma atividade humana, sócio-historicamente determinada, sob pressões internas e externas, com mecanismos e resultados não acessíveis a grande parte da população. Ao proporcionar o conhecimento científico e tecnológico aos alunos, o trabalho docente deve ser direcionado para uma apropriação crítica pelos mesmos, a fim de que estes incorporem ao seu universo de representações sociais e constituam uma "cultura", ultrapassando a prática da "ciência morta".

Quanto ao conhecimento fruto de pesquisas neurocientíficas, houve um maior interesse por parte dos cientistas e da população em geral neste assunto. Entretanto, as discussões sociais e éticas resultantes não são compartilhadas com a sociedade. Tais discussões podem ser incorporadas de forma mais aprofundada em futuras pesquisas com o tema aqui desenvolvido. 


\title{
Interlocution between neuroscience and meaningful learning: a theoretical proposal for the teaching of genetics
}

\begin{abstract}
This literature review aimed to verify the possibility of linking neuroscientific knowledge with the Ausubel's Meaningful Learning Theory as a proposal to facilitate the teaching and learning of Genetics. The results of this review showed that the central concepts of the Meaningful Learning Theory (cognitive structure, previous knowledge, mechanical and meaningful learning, concept maps) present a deep neurophysiological correlative, therefore the interlocution between Neuroscience and the Meaningful Learning is possible. Therefore, Neuroscience associated with the Meaningful Learning Theory results in a neurocognitive approach, which allows a better understanding of the neural and cognitive mechanisms involved in the teaching and learning process and, based on that, it can offer important theoretical and practical basis for the teaching work, facilitating the significant learning of Genetics.
\end{abstract}

KEYWORDS: Neuroscience. Meaningful learning. Teaching of genetics. 


\section{AGRADECIMENTOS}

A CAPES pelo apoio financeiro.

\section{NOTAS}

1 David Paul Ausubel (1918-2008), médico psiquiatra de formação, dedicou grande parte da sua carreira acadêmica a uma visão cognitivista da psicologia educacional. Sua teoria da Aprendizagem Significativa tem sido amplamente divulgada pelos professores Joseph D. Novak e Marco Antonio Moreira (MOREIRA, 1999).

2 Existe uma clara distinção entre dificuldade escolar (DE) e transtorno de aprendizagem (TA). As DE envolvem problemas de origem pedagógica e/ou sociocultural, sem qualquer envolvimento orgânico.

O TA relaciona-se com comprometimentos na estrutura e/ou funcionamento cerebral, envolvido no ato de aprender, tais como dislexia, discalculia e transtorno da escrita. Além dos TA, outros problemas neurobiológicos como o Transtorno de Déficit de Atenção e Hiperatividade (TDAH) também estão relacionados com o mau desempenho escolar (SIQUEIRA e GURGEL-GIANNETTI, 2011).

3 A teoria cognitiva inclui várias vertentes: a teoria da Gestalt e psicologia fenomenológica (Kofka, Köhler, Whertheimer, Maslow, Rogers), psicologia genético-cognitiva (Piaget, Bruner, Ausubel, Inhelder) e a psicologia genéticodialética (Vygotsky, Luria, Leontiev, Rubinstein, Wallon) (PÉREZ GOMÉZ, 2000).

4 Neocórtex - "novo córtex" ou "córtex mais recente" compreende a região evolutivamente mais recente do cérebro dos mamíferos. Esta região recobre os lobos cerebrais, apresenta cerca de 30 bilhões de neurônios, os quais estão divididos em seis camadas de neurônios com função e morfologia diferentes (BALEY, 2005).

5 Plasticidade adaptativa é a capacidade do cérebro de alterar seu nível fisiológico em resposta às alterações no ambiente cognitivo (GEAKE e COOPER, 2003).

\section{REFERÊNCIAS}

AGUIAR, J. G.; CORREIA, P. R. M. Como fazer bons mapas conceituais?

Estabelecendo parâmetros de referências e propondo atividades de treinamento.

Revista Brasileira de Pesquisa em Educação em Ciências, v.13, n.2, p.141-157,

2013. Disponível em: <http://revistas.if.usp.br/rbpec/article/view/548/343>.

Acesso em: 16/05/2016.

ANSARI, D.; COCH, D. Bridges over troubled waters: education and cognitive neuroscience. Trends in Cognitive Sciences, v.10, p.4, p.146-151, 2006.

Disponível em:

<http://www.sciencedirect.com/science/article/pii/S1364661306000556>. Acesso em: 16/05/2016. 
AUSUBEL, D. P.; NOVAK, J. D.; HANESIAN, H. Psicologia Educacional. Rio de Janeiro: Interamericana, 1980.

BACHELARD, G. A filosofia do não. São Paulo: Abril Cultural, 1978.

A formação do espírito científico. São Paulo: Contraponto, 1996.

O novo espírito científico. Lisboa: Edições 70, 1982.

BADDELEY, A. Working memory and language: an overview. Journal of Communication Disorders, v.36, n.3, p.189-208, 2003. Disponível em: <http://www.sciencedirect.com/science/article/pii/S0021992403000194>. Acesso em: 16/05/2016.

BALEY, C. A. Concept Mapping: A Neuro-Scientific Approach. In: Midwest Research-to-Practice Conference in Adult, Continuing, and Community Education, University of Wisconsin-Milwaukee, Milwaukee, WI. 2005. Disponível em: $<$ https://scholarworks.iupui.edu/bitstream/handle/1805/631/02.pdf?sequence= 1>. Acesso em: 30/04/2016.

BRAGA, R. G.; MATOS, S. A. Kronus: refletindo sobre a construção de um jogo com viés investigativo. Experiências no Ensino de Ciências, v.8, n.2, p.1-19, 2013. Disponível em: <http://if.ufmt.br/eenci/artigos/Artigo_ID206/v8_n2_a2013.pdf>. Acesso em: 16/05/2016.

BRASIL, Ministério da Educação e Cultura. Diretrizes Curriculares Nacionais da Educação Básica. Brasília, 2013. Disponível em:

$<$ http://portal.mec.gov.br/index.php?option=com_docman\&view=download\&ali as=15548-d-c-n-educacao-basica-nova-pdf\&Itemid=30192>. Acesso em: $16 / 05 / 2016$.

Parâmetros Curriculares Nacionais para o Ensino Médio (PCNEM). Brasília, 2000. Disponível em: <http://portal.mec.gov.br/seb/arquivos/pdf/CienciasNatureza.pdf >. Acesso em: 16/05/2016.

CAMARGO, S. S.; INFANTE-MALACHIAS, M. E. A genética humana no ensino médio: algumas propostas. Genética na Escola, v.2, n.1, p.14-16, 2007. Disponível em:

<http://media.wix.com/ugd/b703be_213a6a6514ba4157b7327c516b634d33.pdf >. Acesso em: 16/05/2016. 
CAMPO-CABAL, G. Biología del aprendizaje. Revista Colombiana de Psiquiatría, v.41, p.22-30, 2012. Disponível em:

<http://www.scielo.org.co/pdf/rcp/v41s1/v41s1a03.pdf>. Acesso em: 16/05/2016.

CARDOSO, M. M. L.; CARDOSO, T. A. L.; SILVA, M. L. S. Proposta de atividade lúdica para a aprendizagem de conceitos em genética. Revista Didática Sistêmica, v.12, p.148-161, 2010. Disponível em: <https://www.seer.furg.br/redsis/article/view/1851/1013>. Acesso em: $16 / 05 / 2016$.

CARVALHO, F. A. H. Neurociências e educação: uma articulação necessária na formação docente. Trabalho, Educação e Saúde, v.8, n.3, p.537-550, 2011. Disponível em: <http://www.scielo.br/pdf/tes/v8n3/12.pdf>. Acesso em: 16/05/2016.

CARVALHO, J. C. Q.; COUTO, S. G.; BOSSOLAN, N. R. S. Algumas concepções de alunos do ensino médio a respeito das proteínas. Ciência \& Educação, v.18, n.4, p.897-912, 2012. Disponível em:

<http://www.scielo.br/pdf/ciedu/v18n4/v18n4a10.pdf>. Acesso em: 16/05/2016.

CHRISTODOULOU, J. A.; GAAB, N. Using and misusing neuroscience in educationrelated research. Cortex, v.45, n.4, p.555-557, 2009. Disponível em: <http://www.sciencedirect.com/science/article/pii/S0010945208001615>. Acesso em: 16/05/2016.

CHU, Y. C.; REID, N. Genetics at school level: addressing the difficulties. Research in Science \& Technological Education, v.30, n.3, p.285-309, 2012. Disponível em: <http://www.tandfonline.com/doi/pdf/10.1080/02635143.2012.732059>. Acesso em: 16/05/2016.

COLLINS, A. M.; QUILLIAN, M. R. Retrieval time from semantic memory. Journal of verbal learning and verbal behavior, v.8, n.2, p.240-247, 1969. Disponível em: <http://gureckislab.org/courses/fall15/lhc/readings/cq69.pdf>. Acesso em: 16/05/2016.

CONSENZA, R. M.; GUERRA, L. B. Neurociência e educação: como o cérebro aprende. Porto Alegre: Artmed, 2011.

CORREIA, P. R. M.; SILVA, A. C.; ROMANO JÚNIOR, J. G. Mapas conceituais como ferramenta de avaliação na sala de aula. Revista Brasileira de Ensino de Física, v.32, n.4, p.4401-4408, 2010. Disponível em: 
DEHN, M. J. Working Memory and Academic Learning: Assessment and Intervention. John Wiley \& Sons, 2008.

DELIZOICOV, D.; ANGOTTI. J. P.; PERNAMBUCO, M. M. Ensino de ciências: fundamentos e métodos. São Paulo: Cortez, 2002.

DEL RÍO, M. J. Comportamento e aprendizagem: teorias e aplicações escolares. In: COLL, C.; PALÁCIOS, J.; MARCHESI, A. (Orgs.). Desenvolvimento psicológico e educação. Porto Alegre: Artmed, 1996, p.25-44.

FLECK, L. Estilos de pensamento na ciência. Mauro Lúcio Leitão Condé (Org.). Belo Horizonte: Fino Traço, 2012.

Gênese e desenvolvimento de um fato científico. Belo Horizonte: Fabrefactum. 2010.

FREIDENREICH, H. B.; DUNCAN, R. G.; SHEA, N. Exploring middle school students' understanding of three conceptual models in genetics. International Journal of Science Education, v.33, n.17, 2323-2349, 2011. Disponível em: <http://www.tandfonline.com/doi/abs/10.1080/09500693.2010.536997>. Acesso em: 16/05/2016.

FREITAS FILHO, J. R. Mapas conceituais: estratégia pedagógica para construção de conceitos na disciplina química orgânica. Ciências \& Cognição, v.12, p.86-95, 2007. Disponível em:

<http://www.cienciasecognicao.org/revista/index.php/cec/article/view/638/420 >. Acesso em: 16/05/2016.

GARCÍA-MADRUGA, J. A.; FERNÁNDEZ-CORTE, T. Learning complex historical knowledge at high school: The role of working memory. Análise Psicológica, v.17, n.2, p.214-252, 1999. Disponível em: <http://www.scielo.mec.pt/pdf/aps/v17n2/v17n2a01.pdf>. Acesso em: 16/05/2016.

GEAKE, J.; COOPER, P. Cognitive Neuroscience: implications for education? Westminster Studies in Education, v.26, n.1, p.7-20, 2003. Disponível em: <http://www.tandfonline.com/doi/abs/10.1080/0140672030260102>. Acesso em: 16/05/2016. 
students. Advance in Physiology Education, v.32, n.4, p.312-316, 2008.

Disponível em: <http://advan.physiology.org/content/32/4/312.full.pdf+html>. Acesso em: 16/05/2016.

GOSWAMI, U. Neuroscience and education. British Journal of Educational Psychology, v.74, p.1-14, 2004. Disponível em:

<http://onlinelibrary.wiley.com/doi/10.1348/000709904322848798/pdf>. Acesso em: 16/05/2016.

Neuroscience and education: from research to practice?. Nature

Reviews Neuroscience, v.7, n.5, p.406-11, 2006. Disponível em:

<http://www.nature.com/nrn/journal/v7/n5/full/nrn1907.html>. Acesso em: $16 / 05 / 2016$.

GUERRA, L. B. Diálogo entre a neurociência e a educação: da euforia aos desafios e possibilidades. Revista Interlocução, v.4, n.4, p.3-12, 2011. Disponível em: <http://interlocucao.loyola.g12.br/index.php/revista/article/viewArticle/91>. Acesso em: 16/05/2016.

HAWKINS, J. On intelligence. New York: Times Books, 2004.

INFANTE-MALACHIAS, M. E. et al. Comprehension of basic genetic concepts by brazilian undergraduate students. Revista Electrónica de Enseñanza de las Ciencias, v.9, n.3, p.657-668, 2010. Disponível em: <http://reec.uvigo.es/volumenes/volumen9/ART9_Vol9_N3.pdf>. Acesso em: 16/05/2016.

IZQUIERDO, A. I. et al. Memória: tipos e mecanismos - achados recentes. Revista USP, v.98, p.9-16, 2013. Disponível em:

<http://www.revistas.usp.br/revusp/article/view/69221/71685>. Acesso em: 16/05/2016.

JUSTINA, L. A. D.; FERLA, M. R. A utilização de modelos didáticos no ensino de Genética - exemplo de representação de compactação do DNA eucarioto. Arquivos do Mudi, v.10, n.2, p.35-40, 2006. Disponível em: <http://periodicos.uem.br/ojs/index.php/ArqMudi/article/viewFile/19924/10818 >. Acesso em: 16/05/2016.

KANDEL, E.; SCHWARTZ, J. H.; JESSELL, T. M. Princípios da Neurociência. 4a ed. São Paulo: Manole, 2003. reasoning ability and learning approaches. Journal of Biological Education, v.48, 
n.2, p.63-70, 2014. Disponível em:

<http://www.tandfonline.com/doi/abs/10.1080/00219266.2013.837402>.

Acesso em: 16/05/2016.

KNIPPELS, M. C. P. J.; WAARLO, A. J.; BOERSMA, K. T. Design criteria for learning and teaching genetics. Journal of Biological Education, v.39, n.3, p.108-112, 2005. Disponível em:

<http://www.tandfonline.com/doi/abs/10.1080/00219266.2005.9655976>. Acesso em: 16/05/2016.

KUHN, T. A estrutura das revoluções científicas. 5a ed. São Paulo: Perspectiva, 2000.

LEMOS, E. S.; MOREIRA, M. A. Avaliação da aprendizagem significativa em biologia: um exemplo com a disciplina embriologia. Aprendizagem Significativa em Revista, v.1, n.2, p. 15-26, 2011. Disponível em:

<http://www.if.ufrgs.br/asr/artigos/Artigo_ID8/v1_n2_a2011.pdf>. Acesso em: 16/05/2016.

LENT, R. Cem bilhões de neurônios? Conceitos fundamentais de neurociência. $2^{a}$ ed. Rio de Janeiro: Atheneu, 2010.

LEWIS, J.; WOOD-ROBINSON, C. Genes, chromosomes, cell division and inheritance - do students see any relationship? International Journal of Science Education, v.22, n.2, p.177-195, 2000. Disponível em: <http://www.tandfonline.com/doi/abs/10.1080/095006900289949>. Acesso em: 16/05/2016.

MARTINEZ, E. R. M.; FUJIHARA, R. T.; MARTINS, C. Show da genética: um jogo interativo para o ensino de genética. Genética na Escola, v.3, n.1, p.1-3, 2008. Disponível em:

<http://media.wix.com/ugd/b703be_1e4ddc1c9f6645d59a2f4d81f788bab1.pdf>. Acesso em: 16/05/2016.

MELO, J. R.; CARMO, E. M. Investigações sobre o ensino de genética e biologia molecular no ensino médio brasileiro: reflexões sobre as publicações científicas. Ciência \& Educação, v.15, n.3, p.593-611, 2009. Disponível em: <http://www.scielo.br/pdf/ciedu/v15n3/09.pdf>. Acesso em: 16/05/2016.

MELLO, C. B. Memória. In: MUSZKAT, M.; MELLO, C. B. Neuropsicologia do desenvolvimento e suas interfaces. São Paulo: All Point Editora, 2008, p.158-172. 
MOREIRA, M. A. Teorias de aprendizagem. São Paulo: Editora Pedagógica Universitária, 1999.

La teoría del aprendizaje significativo: un referente para organizar la enseñanza contemporánea. UNIÓN - Revista Iberoamericana de Educación Matemática, n.31, p.9-20, 2012. Disponível em:

<http://www.fisem.org/www/union/revistas/2012/31/archivo_5_de_volumen_3 1.pdf>. Acesso em: 16/05/2016.

MOREIRA, M. A.; SPERLING, C. S. Mapas conceptuales y aprendizaje significativo: ¿una correlación necesaria?. Experiências em Ensino de Ciências, v.4, n.3, p.91100, 2009. Disponível em:

<http://if.ufmt.br/eenci/artigos/Artigo_ID91/v4_n3_a2009.pdf>. Acesso em: 16/05/2016.

NASCIMENTO, J. V.; MANSO, M. H. S. Aprendizagem significativa em artigos sobre ensino de biologia: uma revisão bibliográfica. Aprendizagem Significativa em Revista, v.4, n.3, p. 53-60, 2014. Disponível em:

<http://www.if.ufrgs.br/asr/artigos/Artigo_ID68/v4_n3_a2014.pdf>. Acesso em: 16/05/2016.

NOVAK, J. D. Learning, creating, and using knowledge: Concept maps as facilitative tools in schools and corporations. New York: Routledge, 2010.

A theory of education: meaningful learning underlies the constructive integration of thinking, feeling, and acting leading to empowerment for commitment and responsibility. Meaningful Learning Review, v.1, n.2, p.1-14, 2011. Disponível em:

<http://www.if.ufrgs.br/asr/artigos/Artigo_ID7/v1_n2_a2011.pdf>. Acesso em: 16/05/2016.

NOVAK, J. D.; CAÑAS, A. J. A teoria subjacente aos mapas conceituais e como elaborá-los e usá-los. Práxis Educativa, v.5, n.1, p.9-29, 2010. Disponível em: <http://www.revistas2.uepg.br/index.php/praxiseducativa/article/view/1298/94 4>. Acesso em: 16/05/2016.

NUNES, F. M. F. Do laboratório à sala de aula: os recentes avanços da Genética. Genética na Escola, v.5, n.1, p.57-61, 2010. Disponível em: <http://media.wix.com/ugd/b703be_5a8647fd41954f2eb077c27f52c8ee50.pdf>. Acesso em: 16/05/2016. 
<http://www.if.ufrgs.br/asr/artigos/Artigo_ID15/v1_n3_a2011.pdf>. Acesso em: $16 / 05 / 2016$

OKEBUKOLA, P. A.; JEGEDE, O. J. Students' anxiety towards and perception of difficulty of some biological concepts under the concept-mapping heuristic.

Research in Science \& Technological Education, v.7, n.1, p.85-92, 1989.

Disponível em:

<http://www.tandfonline.com/doi/abs/10.1080/0263514890070109>. Acesso em: 16/05/2016.

OLIVEIRA, M. L. et al. Genética na TV: o vídeo educativo como recurso facilitador do processo de ensino-aprendizagem. Experiências no Ensino de Ciencias, v. 7, n.1, p. 27-42, 2012. Disponível em:

<http://if.ufmt.br/eenci/artigos/Artigo_ID172/v7_n1_a2012.pdf>. Acesso em: 16/05/2016.

PANIAGUA, A.; VILLAGRÁ, J. A. M. Modelo de estructura cognoscitiva desde el punto de vista de la Teoría Reformulada de la Asimilación. Revista Electrónica de Enseñanza de las Ciencias, v.7, n.1, p.107-130, 2008. Disponível em: <http://reec.uvigo.es/volumenes/volumen7/ART6_Vol7_N1.pdf>. Acesso em: 16/05/2016.

PÉREZ GÓMEZ, A. I. Os processos de ensino-aprendizagem: análise didática das principais teorias da aprendizagem. In: SACRISTÁN, G. J.; PÉREZ GÓMEZ, A. I. (Orgs.). Compreender e transformar o ensino. $4^{a}$ ed. Porto Alegre: Artmed. 2000, p. 27-52.

PEREIRA JR, A. Questões epistemológicas das neurociências cognitivas. Trabalho Educação e Saúde, v.8, n.3, p.509-520, 2011. Disponível em: <http://www.scielo.br/pdf/tes/v8n3/10.pdf>. Acesso em: 16/05/2016.

REID, N. Working memory and science education: conclusions and implications. Research in Science and Technological Education, v.27, n.2, p.245-250, 2009. Disponível em: <http://www.tandfonline.com/doi/pdf/10.1080/02635140902853681>. Acesso em: 16/05/2016.

ROCHE, R. A. P. et al. Prolonged rote learning produces delayed memory facilitation and metabolic changes in the hippocampus of the ageing human brain. BMC Neuroscience, v.10, n.136, p.1-17, 2009. Disponível em: <http://bmcneurosci.biomedcentral.com/articles/10.1186/1471-2202-10-136>. Acesso em: 16/05/2016. 
RODRIGUES, R. F. O uso de modelagens representativas como estratégia didática no ensino da genética: um estudo de caso. Experiências em Ensino de Ciências, v.7, n.2, p.53-66, 2012. Disponível em:

<http://if.ufmt.br/eenci/artigos/Artigo_ID182/v7_n2_a2012.pdf>. Acesso em: 16/05/2016.

ROTTA, N. T. Introdução. In: ROTTA, N. T.; OHLWEILER, L.; RIESGO, R. S. (Orgs.). Transtornos da Aprendizagem: Abordagem Neurobiológica e Multidisciplinar. Porto Alegre: Artmed, 2007, p. 15-20.

SALIM, D. C. et al. O baralho como ferramenta no ensino de genética. Genética na Escola, v.2, n.1, p.6-9, 2007. Disponível em:

<http://www.flipsnack.com/Eveli/revista-genetica-na-escola-volume- 2-numero1-2007.html>. Acesso em: 16/05/2016.

SCHEID, N. M. J.; FERRARI, N. A história da ciência como aliada no ensino de genética. Genética na Escola, v.1, n.1, p.17-18, 2006. Disponível em: <http://media.wix.com/ugd/b703be_6418c0f6af7d445bbd186c47852833e5.pdf $>$. Acesso em: 16/05/2016.

SCHNEIDER, E. M.; JUSTINA, L. A. D.; MEGLHIORATTI, F. A. Investigação do desenvolvimento de um módulo didático sobre o conceito de gene na licenciatura em ciências biológicas. Experiências em Ensino de Ciências, v.8, n.3, p.1-21, 2013. Disponível em:

<http://if.ufmt.br/eenci/artigos/Artigo_ID223/v8_n3_a2013.pdf>. Acesso em: 16/05/2016.

SILVA, A. C. A. Aplicação do programa de neurociência: intervenção em leitura e escrita. 2012. 109f. Dissertação (Dissertação de Mestrado em Educação Especial), Programa de Pós-graduação em Educação Especial: Domínio Cognitivo e Motor, Escola Superior de Educação Almeida Garrett, Lisboa, 2012.

SIQUEIRA, C. M.; GURGEL-GIANNETTI, J. Mau desempenho escolar: uma visão atual. Revista da Associação Médica Brasileira, v.57, n.1, p.78-87, 2011. Disponível em: <http://www.scielo.br/pdf/ramb/v57n1/v57n1a21.pdf>. Acesso em: 16/05/2016.

SOUSA, G. P.; TEIXEIRA, P. M. M. Educação CTS e Genética. Elementos para a sala de aula: potencialidades e desafios. Experiências em Ensino de Ciências, v.9, n.2, p.83-103, 2014. Disponível em:

<http://if.ufmt.br/eenci/artigos/Artigo_ID244/v9_n2_a2014.pdf>. Acesso em: 16/05/2016. 
SOUZA, N. A.; BORUCHOVITCH, E. Mapas conceituais: estratégia de ensino/aprendizagem e ferramenta avaliativa. Educação em Revista, v.26, n.03, p.195-218, 2010. Disponível em:

<http://www.scielo.br/pdf/edur/v26n3/v26n3a10.pdf>. Acesso em: 16/05/2016.

SQUIRE, L. R.; ZOLA, S. M. Structure and function of declarative and nondeclarative memory systems. Proceedings of the National Academy of Sciences of the United States of America, v.93, n.24, p.13515-13522, 1996. Disponível em: <http://www.pnas.org/content/93/24/13515.full.pdf>. Acesso em: 16/05/2016.

TAVARES, R. Aprendizagem significativa, codificação dual e objetos de aprendizagem. Revista Brasileira de Informática na Educação, v.18, n.2, p.4-16, 2010. Disponível em: <http://www.brie.org/pub/index.php/rbie/article/view/1205/1114>. Acesso em: 16/05/2016.

Aprendizagem significativa e o ensino de ciências. Ciências \& Cognição, v.13, n.1, p.94-100, 2008. Disponível em:

<http://www.cienciasecognicao.org/revista/index.php/cec/article/view/687/464 >. Acesso em: 16/05/2016.

TSUI, C. Y.; TREAGUST, D. F. Conceptual change in learning genetics: an ontological perspective. Research in Science \& Technological Education, v.22, n.2, p.185-202, 2004. Disponível em: <http://www.tandfonline.com/doi/pdf/10.1080/0263514042000290895>. Acesso em: 16/05/2016.

VILAS-BOAS, A. Conceitos errôneos de genética em livros didáticos do ensino médio. Genética na Escola, v.1, n.1, p.09-11, 2006. Disponível em: <http://media.wix.com/ugd/b703be_7b89a73418c349e2870208c22d05fc34.pdf> . Acesso em: 16/05/2016

ZULL, J. E. The Art of Changing the Brain: Enriching the Practice of Teaching by Exploring the Biology of Learning. Sterling, Virginia: Stylus Publishing, 2002. 
Recebido: 04 mai. 2016

Aprovado: 24 mai. 2016

DOI: http://dx.doi.org/10.3895/rbect.v9n2.3947

Como citar: SANTOS, F. S.; FRANCISCO, A. C.; KLEIN, A. I.; FERRAZ, D. F. Interlocução entre neurociência e aprendizagem significativa: uma proposta teórica para o ensino de genética. Revista

Brasileira de Ensino de Ciência e Tecnologia, v. 9, n. 2, 2016. Disponível em:

$<$ https://periodicos.utfpr.edu.br/rbect/article/view/3947>. Acesso em: xxx.

Correspondência:

Fabio Seidel dos Santos:

Av Monteiro Lobato, Km 04, 84010-060, Ponta Grossa, Paraná

Direito autoral: Este artigo está licenciado sob os termos da Licença Creative Commons-Atribuição 4.0

Internacional.

(c) (1) 